\title{
UNUSUAL NEST SITE \\ OF BROWN THRASHER
}

JEAN BANCROFT, 306 - 200 Tuxedo Boulevard, Winnipeg, Manitoba. R3P OR3

From 26 to 28 May 1993, I visited Grand Marais, on the south basin of Lake Winnipeg, as the guest of Letty and Ernie Taylor. Soon after my arrival I meandered down one of the lanes and heard and saw at a distance a singing Brown Thrasher perched in the top of a wayside tree. Its melodious song presumably was to attract a mate and establish a territory. The Brown Thrasher belongs to the same family (Mimidae) as the Northern Mockingbird and Gray Catbird, both notable songsters. It is said that this thrasher often tries to "out-catbird the catbird." $A$ retiring, solitary bird, "This mimic thrush has remarkable vocal skills."

The nest site is "probably selected by the female" and "may or may not be near the singing tree."1 But I decided to go out early the next morning to where I had heard the male. I stood close to a small wooded area by the lane and was pleasantly surprised when a Brown Trasher flushed from inside a depression in a snag. This snag was about $5 \mathrm{ft}$. tall and 34 in. in circumference. A bulky nest built of twigs, dried leaves and rootlets was nestled approximately $51 / 2$ in. down inside the snag. Bent and other authors mention that the majority of Brown Thrasher nests are built 2-7 ft. above the ground in shrubs or trees. ${ }^{1,3,4,6,8}$ In May 1992, at Grand Marais, I observed a pair of Brown Thrashers carrying twigs and dried leaves to a nest site on the ground in a small wooded area. Many years ago I ob- served a nest, across the lake at Whytewold, in a low bushy spot close to a fence. A nearby resident told me at that time she was watching another thrasher nest underneath her bedroom window.

I was unable to stay at Grand Marais to follow the outcome of the nest in the snag but Ernie Taylor kindly kept observations for me. On 4 June he took a picture through the thickened foliage with a telephoto lens; it shows four eggs, the usual number expected. ${ }^{3,4,8}$ Incubation takes $12-14$ days and is shared by both sexes. ${ }^{4,8}$ On 10 June, according to Ernie, both adults gave loud calls and he discovered there were only two eggs in the nest (see photo). When he checked the nest on 15 June at 8:20 a.m. he found the nest empty. There were no signs in the nest, or nearby, of any broken shells. The nest could have been predated, but I suspect that it was lost following parasitism. The Brown Thrasher is the largest passerine known to be parasitized by the Brown-headed Cowbird; the latter removes host eggs about the time it lays. ${ }^{1,4}$

A photo taken by Taylor on 10 June shows what appears to be a cowbird egg, though the picture is not clear enough to be certain of this. When he next visited the nest on 3 July, the nest remained empty and there were no thrashers present.

I have often wondered why this bird was named Brown Thrasher. I 


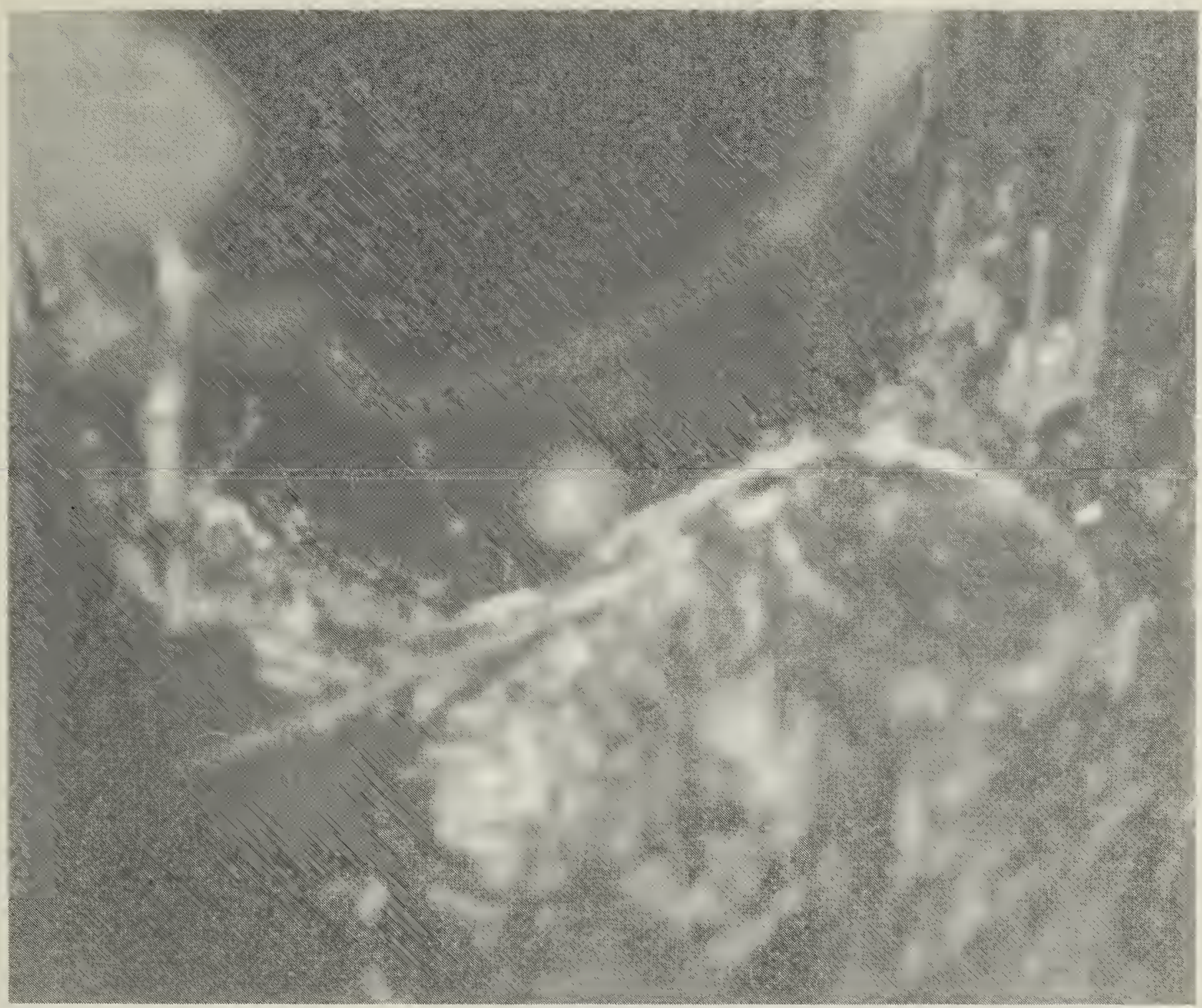

can understand the colour, but "thrasher"? Some authors suggest that the name comes from its habit of thrashing about among the leaves and rubbish; another suggestion is related to the bird's habit of thrashing large insects or other prey, that is, beating them against the hard ground to kill or mutilate them. ${ }^{1,7}$ Though unfamiliar to many people, this attractive songster is another creature of benefit to mankind. Much of its food consists of invertebrate animals, spiders, moths, beetles, caterpillars, etc. Wild fruits and weed seeds form a lesser part of its diet.

The breeding distribution of the Brown Thrasher is in southern Canada as far west as southeastern Alberta. It is accidental in Churchill. This bird winters in the southern United States, especially those bordering on the Gulf of Mexico. ${ }^{4}$
I wish to thank Robert W. Nero for his constructive criticism of an earlier draft of this article.

1. BENT, A.C. 1948. Life histories of North American nuthatches, wrens, thrashers, and their allies. US Natl. Mus. Bull. 195. Dover reprint (1964). $475 \mathrm{pp}$.

2. DENNIS, J.V. 1991. A guide to western bird feeding. Bird Watcher's Digest Press, Marietta, Ohio. 192 pp.

3. GODFREY, W.E. 1986. The birds of Canada. Natl. Mus. Nat. Sci. Ottawa. $595 \mathrm{pp}$.

4. HARRISON, H.H. 1975. A field guide to birds' nests in the United States east of the Mississippi River. Houghton Mifflin, Boston. 257 pp.

5. MACDONALD, M. 1947. The birds of Brewery Creek. Oxford University Press, Toronto. 334 pp.

6. NATIONAL GEOGRAPHIC SOCIETY. 1986. Field guide to the birds of 
North America. 2nd ed. Washington. $464 \mathrm{pp}$.

7. NATIONAL GEOGRAPHIC SOCIETY. 1964. Song and garden birds of
North America. Washington. 400 pp.

8. STOKES, D.W. and L.Q. 1983. A guide to bird behaviour, Vol. 11. Little Brown and Co., Boston. 334 pp.

\section{Thrasher}

Mostly they skulk in thickets giving us uncertain glimpses as they perform their chores, a flash of dappled brown the rust of old oak leaves, but I saw one dancing at noon running on a hot sandy road repeatedly pecking the ground then swiping its head sideways down onto the shining sand, frenzied with ants, I guessed, as it urgently pranced erect before flying to shaded glades.
Catch them at dawn in song when they perch up high singing twice-repeated whistled phrases melodies that quiet cows or foxes, then their striped breast glows that russet tail hangs still and all the urgent woods thrill.

- Robert W. Nero, Wildlife Branch, Box 24, 1495 St. James Street, Winnipeg, Manitoba. R3H OW9

\section{SNOWY OWL CAPTURES ROCK DOVE IN MID-AIR}

ROBERT W. NERO, Wildlife Branch, Box 24, 1495 St. James Street, Winnipeg, Manitoba. R3H OW9

Snowy owls are known to take a variety of birds as prey, including pheasants, grouse, ducks, gulls, and Rock Doves, that is, common pigeons. ${ }^{1,2}$ The actual capture of a pigeon, however, is rarely witnessed. On 24 January 1994, shortly after I left the office in an industrial section of Winnipeg, I saw this happen (corner of Wellington and St. James). I was driving south at about 2:00 p.m.; just as I slowed for cars stopping at an intersection, a large dark bird flapping high overhead caught my attention. I was looking into the sun and the bird appeared black, hence my initial belief that it was a Common Raven. It appeared to be involved with three pigeons, but was it harassing them? Or was it the other way around? Just then, it reappeared from behind a building for a moment and I knew it was not a raven. I quickly turned off into a driveway, jumped out and searched the sky. It was a bright sunny day, just a little hazy, and I held my hand to shield my eyes from the sun. And, yes, "Snowy Owl!", I exclaimed. It was circling about at a height of perhaps 24 metres. As I watched, puzzled by its behaviour, it flew towards two more pigeons which were flying slowly westwards, across a strong north wind, wings upheld in the display so common to their kind. When they dropped down, the owl wheeled about and a moment later circled back towards yet another approaching pigeon, a lone bird also flying westwards. The owl gained steadily on the pigeon, overtook it and then, to my utter delight, seized it. "It caught it!", rang through my mind. 